\title{
Status of Research on Refining, Analysis, Testing and Products*
}

\author{
Yutaka Katayama**
}

Research work on petroleum in Japan during the last four years since 1963 has been carried out very actively. It is beyond the scope of his paper to cover all of the published works.

This paper is to present a review of researches appeared mainly in the Journal of the Japan Petroleum Institute, Journal of the Fuel Society of Japan, Journal of Japan Society of Lubrication Engineers, and also papaer presented at the Annual Meetings of the Chemical Society of Japan and the Japan Petroleum Institute.

\section{Refining}

The feature subjects have been focussed to the research on catalysts of catalytic cracking and catalytic reforming and on lube oil hydrotreating. Recently, the research on hydrodesulfurization of residues has been extended in research activities.

With hydrotreating, Y. Sakai et al. ${ }^{1{ }^{2}}$ reported that composition changes during the treating largely depend upon their crude source and for oxidation stability of the treated oils, optimum sulfur content would be present. T. Kotani et al. ${ }^{3)}$, S. Funakoshi et al."), T. Furukawa et al. ${ }^{5}$, and K. Iijima et al.' showed that hydrogen treated lubricating oils such as spindle, turbine, machine and motor oils have rather favorable properties than acid treated ones. Y. Oguchi et al." studied on hydrotreating of engine oils and found hydrotreated oils nearly the same qualities as the sulfuric acid-clay treated ones. Studies on hydrodesulfurization of thiophene in benzene over $\mathrm{V}_{2} \mathrm{O}_{3}-\mathrm{MoO}_{2}$ catalyst by $\mathrm{K}$. Tarama et al. ${ }^{8}$ and that of light sulfur compounds over nickel-sulfide catalyst by A. Okagami et al." were also reported.

T. Yamaguchi et al. ${ }^{10}$ discussed the characteristics of catalyst particle movement in

* Received November 2, 1966 .

** General Manager of Central Technical Research Laboratory, Nippon Oil Company, Ltd. fluid catalytic cracking, and Y. Kunugi et al. ${ }^{11)}$ studied other reactions than cracking.

N. Yamamoto et al. ${ }^{12,13}$ made a study on $n$-pentane isomerization over platinum-zeolite catalyst (molecular sieve $13 \times$ ). H. Yoshida et al. ${ }^{(4) \sim 16)}$ reported on the activity, selectivity and the method of preparation of the cogelated chromia-alumina catalyst, useful to aromatization of paraffln rich naphtha. $\mathrm{H}$. Hayashi et al. ${ }^{17}$ ) found $\mathrm{Ni}_{3} \mathrm{~S}_{2}$ catalyst which can completely hydrogenate diolefins in steam cracked naphtha without aromatics hydrogenation.

N. Yata et al. reported on urea-dewaxing of residue using mixture of methanol and benzene ${ }^{181}$, and separation of $n$-paraffln from middle distillates by urea ${ }^{19}$.

Some studies such as desulfurization of petroleum by microorganism and sulfonation of lubricating oils were made by N. Sakikawa et $\mathrm{al} .{ }^{20)}$ and $\mathrm{M}$. Hirohama et al. ${ }^{21}$ respectively.

Many studies on the corrosion of refinery equipment and the anti-corrosion materials have appeared in J. Japan Petr. Inst. ${ }^{.22)-571}$

\section{Analysis and Testing}

Utilization of instrument has been increasing with greater demand for analysis of trace components. Dominant works in this field have been gaschromatographic analysis.

$\mathrm{T}$. Kunugi et al. ${ }^{28), 28}$ studied the fundamental performance of a self-devised capillary column and analyzed whole $\mathrm{C}_{1}-\mathrm{C}_{5}$ paraffin-olefine mixtures in about 25 minutes. H. Miyake et al. ${ }^{30,31)}$ made a complete analysis of $\mathrm{C}_{6}-\mathrm{C}_{10}$ aromatic hydrocarbons with squalane and polypropylene glycol column. S. Tago et al. ${ }^{32)-34)}$ established the gaschromatographic analysis of trace components in thermal cracked gases; acetylene in ethylene, methyl acetylene and propadiene in $\mathrm{C}_{2}-\mathrm{C}_{5}$ hydrocarbon mixtures containing a large amount of ethylene and propylene and acetylene in $\mathrm{C}_{4}$ fractions.

I. Takizawa et al. $^{35), 36)}$ made a preparative 
gaschromatographic apparatus and studied preparation of butene isomers. Other reports on gaschromatographic analysis were as follows: analysis of thermal cracked gasolines, analysis of $\mathrm{C}_{6}-\mathrm{C}_{10}$ alkylbenzenes in crude oils, naphthanes in reformates and cracked gasolines by a combination of fractional distillation, adsorption with silica gel and gaschromatography. ${ }^{38)}$

S. Oshima et al. ${ }^{39-42}$ have been systematically working on the application of mass spectroscopy to petroleum industry. Some of their works are quantitative analysis of hydrocarbons in gas oils and type analysis of alkyl side chains of heavy aromatics.

A. Shimazu et al. ${ }^{43), 44}$ analy zed alkyl radicals of dialkyldithiophosphates from the intensity of infrared absorption, and also determined hindered phenols by compensation method, extracting them from the sample with alcohol- $\mathrm{H}_{2} \mathrm{O}-\mathrm{KOH}$ mixed solvent.

S. Tanaka et al. $^{45}$ determined polybutene in lube oils by selective sedimentation, silica gel chromatography and inf rared spectroscopy. By using infrared spectroscopy, K. Hasegawa et al. $^{46}$ determined anti-icing additives in jet fuels extracting them with water.

Regarding metal analysis, X-Ray fluorescence spectroscopy and atomic absorption spectroscopy were increasingly applied to this field. K. Hasegawa et al. ${ }^{47,4{ }^{3}}$ reported simultaneous determination of lead and bromine in gasoline and sulfur, cadmium and barium in lubricating oils by X-Ray fluorescence spectrometry.

Some of other works were as follows; sulfur determination of various petroleum products by 0 . Shimada et al. ${ }^{49}$ and sulfur, chlorine and iron in plant scale by $\mathrm{K}$. Ishida et al. ${ }^{50}$

Of polarographic analysis, S. Musha et al. ${ }^{51)}$ determined vanadium content in crude oils in 30 minutes, and also zinc, lead and cadmium simultaneously, comparing them with the results by atomic absorption spectroscopy ${ }^{52}$. They also applied atomic absorption spectroscopy to manganese determination in gasoline ${ }^{53)}$. Of other interesting works, $\mathrm{K}$. Ishida et al. ${ }^{54)}$ observed the powder X-Ray diffraction pattern of engine deposits and found out its main components to be $\mathrm{PbX}_{2}$,
$\mathrm{PbO}_{2}$ and $\mathrm{PbSO}_{4}$, and $3 \mathrm{~Pb}_{3}\left(\mathrm{PO}_{4}\right)_{2} \cdot \mathrm{PbX}$ in the case of gasoline contained organic phosphorous additive.

Other interesting works are elementary analysis of hydrocarbons by X-Ray compton scattering by $\mathrm{K}$. Hasegawa et al $^{55,56)}$, application of high resolution NMR to quantitative analysis of hydrocarbon mixtures by $\mathrm{T}$. Takeuchi et al. ${ }^{57}$, silica gel chromatographic determination of wax content in asphalt by S. Sato et al. ${ }^{58}$, hydrogen determination in petroleum products with $\beta$-ray $\mathrm{H} / \mathrm{C}$ meter by $Y$. Nose et al. ${ }^{59}$, volumetric analysis of minute amount of acetylenes by $\mathrm{T}$. Omori et al. $^{60}$, and determination of trace amount of water in greases with modified Karl Ficsher reagent by K. Muroi. ${ }^{611}$

In the field of viscosity measurement, $M$. Onoyama et al. ${ }^{62}$ measured the viscosity of used oils and fuel oils by Brookfield Rotational Viscometer,

M. Kinoshita et al. ${ }^{63), 64)}$ studied rheologicalbehavior of polymer solutions with suspendedlevel type master viscometer under various pressure.

In the activities of Section 5, Japan Petroleum Institute, Committee of Hydrocarbon Type Analysis performed ${ }^{65}$ a crosscheck of hydrocarbon type analysis of gasolines on FIA method and reported that repeatability was satisfied, but in case of olefin rich sample, reproducibility would have been unsatisfied within $3 \%$ accuracy without standerdization of determing the boundary layer between olefine and aromatic. Committee of Neutralization Value Test method presented ${ }^{66}$ the current status of accuracy of the neutralization value test of lube oil on the result of cross-check.

\section{Products}

\section{Motor Gasolines}

T. Shigeta ${ }^{6 *}$ reported the results of the comparative tests on Research and Motor octane numbers, in which most petroleum laboratories participated.

K. Yamazaki et al. ${ }^{69 /-75)}$ made a series of studies about the effects of engine operating conditions on knocking characteristics of gasolines, which were evaluated by the incipient knock limited compression ratio in 
a CFR engine. The main conclusions were as follows; the lead responses of reformed and cracked naphtha were greater at rich fuel-air ratio and at retarted ignition timing. The time of knock varied among the fuels having the same antiknock properties, and the phenomena were explained by the ignition delay. An empirical equation relating knocking characteristics with inlet-mixture temperature was developed from the knock limited compression density.

T. Ogawa presented a method to estimate Research octane number from gravity, distillation and tetraethyl lead content ${ }^{76}$.

The Road Octane Number Committee of the Japan Petroleum Institute started its annual survey of the octane number requirements of domestic passenger cars in 1959. The results during the first 5-year-period dealing with 497 cars of 1959-1963 models, were reported $^{77}$. The requirement in Research octane number which satisfied $90 \%$ of 1963 model car population was 95 with primary reference fuels, 96 with cracked naphthawhole straight naphtha blends and 100 with reformed naphtha-light straight naphtha blends, which were about 3 octane numbers higher than that of 1960 model cars. Majority of cars used, about $80 \%$ in 1963, showed their maximum requirement at $1,000 \mathrm{rpm}$, which was the lowest engine speed determined.

K. Uchinuma et al. ${ }^{79,80)}$ made a field survey of knock. Knocks occured frequently at very low engine speed during full throttle acceleration, showing that this condition was realistic as the road knock test condition. The effect of car model, driver and traffic condition on knock was discussed. Knocks during part throttle acceleration also occurred frequently. They reported that the octane number requirement at $51 \mathrm{mmHg}$ manifold vacuum of four cars used were approximately equal to or higher than those at full throttle.

T. Takahashi ${ }^{81)}$ studied on surface ignition in a small 2 cycle engine and a CFR engine. Fuel Oils

The majority of studies dealt with colloidal properties of fuel oils, combustion performance in engines and boilers and the effect of additives on fuel oil.
As for rheological properties, Y. Yuhara et al ${ }^{82)}$ evaluated fuel oils by using rotating viscometer, and A. Arai et al. ${ }^{83)}$ evaluated additive effects on deposit formation.

Concerning with combustion performance of fuel oils, $\mathrm{N}$. Kita et al ${ }^{84}$ made a comparative engine performance test of gas oil, fuel oil, and crude oil. The same problem was dealt with by S. $\mathrm{Jo}^{85}$, M. $\mathrm{Seo}^{86)}$, and F. Nagao ${ }^{87}$.

A joint study ${ }^{88}$ on combustion in boilers was made by the Section 5, Japan Petroleum Institute. H. Iijima et al. ${ }^{88}$ reported independently a series of similiar studies. $\mathrm{T}$. Sagai et al. ${ }^{90}$ studied on fuel oil additives. Y. Arai et al. ${ }^{\text {91) }}$ studied on colored smoke oil which produced a colorful Olympic mark in the sky with five jet planes at the opening ceremony of the Tokyo Olympic game.

Crankcase Oils

Utilization of radioisotopes as tracer has been active in this field. N. Yamaki et al. ${ }^{100}$ discussed the effect of engine operating conditions on wear rate of piston ring by using Petter AV-1 laboratory engine mounted with irradiated piston ring. K. Kishigami et al. ${ }^{101}$ studied the effect of fuel quality and additive dosage on piston ring wear by single cylinder Fulperland diesel engine. Y. Nose ${ }^{102}$ reported that the abnormal piston ring wear at low temperatures in Lauson engine is not due to corrosion susceptible to low temperatures during the shut down period but to the low temperature at start-up. S. Furuhama et al. ${ }^{103)}$ recognized, studying top ring wear of Datsun Blue-Bird engine, that the wear of upper and lower iron sides was greater than that of chromium plating face, and that the wear of iron side is strongly affected by oil viscosity. He also studied on the rotating behavior of piston ring under various operating conditions by air-coold single-cylinder engine $^{104)}$. K. Hasegawa ${ }^{105)}$ studied the behavior of lubricant in small air-cooled two-strokecycle engine by using lubricant containing ${ }^{35}$ S-labelled sulfurized oleic acid.

Field tests by taxi and bench tests by domestic engine were actively conducted. $\mathrm{H}$. Shibusawa et $\cdot{ }^{\circ} .^{106}$ ) conducted modified ASTM MS Sequence I, II, and III tests with Toyopet $R$ type engine and reported that it is possible to anticipate MS oil performance in field 
tests from varnish ratings in the bench tests. M. Ishimaru et al. ${ }^{107)}$ developed modified ASTM Sequence V Test Procedure using Datsun engine, and reported that ashless detergents are considerably effective even though the displacement is below 2,000 cc. ${ }^{106,108), 108)}$ M. Tsuge et al. ${ }^{110}$ devised a reciprocal moving tester for studying oil-up through piston ring. S. Furuhama et al. ${ }^{11)}$ measuring the temperature of piston parts in two-stroke-cycle-engine, found that piston foulings will occur over boundary temperature which is approximately $320^{\circ} \mathrm{C}$ at crown center.

As for diesel engine oils, S. Kamio et al. ${ }^{112}$ reported that the number of diesel cars increases year by year as used by the Japan National Railways, and that oil change period was lengthened by improved quality of heavy duty oil. S. Yoshida et al. ${ }^{113}$ measured the ring-groove temperature of Caterpillar 1-A, 1-D, 1-G, 1-H, and Petter AV-1 under ordinary operating conditions by using alumelconstantan thermocouple. Engine performance of hydrofined lube oils by T. Yoshino et al. ${ }^{144}$, Y. Oguchi et al. ${ }^{7}$, and Y. Sakai et al. ${ }^{115}$ ) were reported.

Studies were made of marine diesel engine lubricants such as experimental studies of crosshead pin bearing by $\mathrm{Y}$. Wakuri et al. ${ }^{116)}$ field test of marine diesel lubricants by $M$. Ogawa ${ }^{188}$ and A. Wakana et al. ${ }^{119}$ ) and bench test based on Bolnes engine by M. Ishimaru et al. $^{1203}$

As for analysis of used oil, T. Ohashi et al. ${ }^{121}$ discussed oil-deterioration from electronmiscroscopic observation of insolubles and quantitative measurement of insolubles by miliporefilter.

For identification of alkyl groups of zinc dithiophosphates, I. Shimazu et al. ${ }^{92)}$ applied infrared spectroscopy and I. Shimizu ${ }^{67}$ did partition chromatography. Both S. Kamio et al. $^{93)}$ and T. Sakurai et al., ${ }^{94)}$ studied on thermal decomposition mechanism of zinc dithiophosphates. T. Sakurai et al. studied reaction kinetics of extreme-pressure additives to iron with sulfur compounds ${ }^{95}$ and in the coexistence of sulfur- and chlorine- compounds ${ }^{96)}$ and they discussed the reaction of these compounds to iron at high temperature $^{97), 88)}$. Another study was made by them of the micelle formation and adsorption of metal sulfonates in non-aqueous system ${ }^{89}$. Grease

Quantities of domestic production of long life ball and roller bearing greases are increasing and $\mathrm{MoS}_{2}$-containing greases run in the market.

M. Nagano et al. ${ }^{122}$ prepared $\mathrm{Li}$ greases and $\mathrm{Na}$ greases under various cooling conditions and found that the phase transition temperature are strongly affected by cooling conditions.

M. Hoshino et al. ${ }^{123)}$ pointed out that the high temperature viscosity of greases by a rotating viscometer is related to the leakage of grease at high temperatures. T. Oguchi et al. ${ }^{124}$ determined the lowest pumpable temperature of greases in actual feed pipes by ASTM apparent viscometer. A. Kobayashi ${ }^{128}$, reported that the low temperature viscosity is closely related to low temperature start up torque in a rolling bearing. T. Shonozaki et al. ${ }^{125)}$ observed the movement of grease in the ball bearing by using dyes and radioisotopes.

The frictional and wear characteristics of various kinds of silicone greases by $\mathrm{Y}$. Moniwa et al. ${ }^{126)}$ the effects of load, running speed, bearing temperature and volume of grease on grease service life in sealed ball bearing by $\mathrm{S}$. Ono et al. ${ }^{127}$, factors affecting bearing torque under various conditions by K. Ono et $a .^{129)}$, E.P. greases in use for tension by $\mathrm{Y}$. Moniwa et al. ${ }^{130}$, observation of deteriorated greases under load by electronmicroscopy and infrared spectroscopy by $\mathrm{T}$. Chiku et al. ${ }^{131}$ ) were reported.

\section{Rust Preventive Oil}

$K$. Oma et al. ${ }^{132}$ surveyed the effect of weather on steel corrosion in various districts in Japan. H. Sugahara et al. ${ }^{133}$ studied $\mathrm{SO}_{2}$ corrosion of mild steel in the air.

S. Fujii et al. ${ }^{134)}$ developped the study on the rust preventive action of amine type inhibitor in concept of association and adsorption ability and intra-molecule $\mathrm{H}$-bond.

M. Koike et al. ${ }^{1352}$ reported that various types of additives indicate characteristic behavior in the rust proof tests.

Rolling Lubricants

K. Saeki et al. ${ }^{136,137)}$ found out the rolling 
lubrication characteristics of rolling lubricants could be estimated by a pendulum type oiliness tester or a thin plate rolling tester as well as a laboratory rolling mill. E. Tanaka et al. ${ }^{138)}$ tried to evaluate rolling oils by a cylindrical rolling tester. T. Mizuno ${ }^{139)}$ proposed a new parameter which represents hydrodynamic effects on volume of lubricant in the contact arc.

A. Yoshioka ${ }^{140}$ found effective additives for cold rolling lubricants for aluminum.

M. Nagano et al. ${ }^{141}$ reported a laboratory test method to evaluate the performance of lubricating oil for machine tool slideways.

Turbine Oils and Insulating Oils

Y. Moniwa ${ }^{1+2}$ ' reported that EP turbine oil has similar properties to conventional turbine oil except EP characteristics, and $\mathrm{H}$. Kurosawa ${ }^{143)}$ determined DBPC in used turbine oils for lubrication control.

H. Fujita ${ }^{144}$ reported that the gassing tendency of insulating oils under electric stress was affected in accordance with the aromatic content. S. Kimura ${ }^{145)}$ studied on copper corrosion by free sulfur produced in sulfuric acid treatment.

\section{Asphalt}

S. Sakagami et al. ${ }^{146)}$ studied the change of asphalt components due to ultra-violet irradiation, and K. Murayama as well studied the asphalt component change in blowing by BM and Texaco method ${ }^{147,143)}$. M. Otsuka et al. ${ }^{149}$ studied non-hydrocarbon components in asphalt.

On fluidity of asphalt, transition from non-Newtonian flow to Newtonian flow nearly at softening point, ${ }^{147}$, and visco-elasticity of mineral-filled asphalt at low temperatures were reported.

T. Horio ${ }^{151)}$ studied the influence of rheological properties of asphalt on the characteristics of asphaltic paving mixture. C. Itakura et al. reported the rheological proper ties of Gussasphalt ${ }^{152)}$ and correlation between Marshall test and wheel tracking test ${ }^{153}$. Other papers in this field as follows; mechanical properties of asphalt at low temperatures $^{154)}$, the relation between Fraas brittle point and general properties of asphalt ${ }^{155}$, effect of blowing on oil-exudation of products $^{156)}$ and change of the dielectric pro- perty ${ }^{157}$, practical performace of paving asphalt, and asphalt anti-stripping agents ${ }^{158,158)}$. Friction, Wear, Lubrication

M. Toyoguchi et al. ${ }^{(60) \sim 163)}$ studied on the effect of lubricant additives on wear between phosphorous bronze and steel by four ball tester and pendulum type oiliness tester. $\mathbf{S}$. Aoki et al. ${ }^{165)}$ studied on fretting corrosion in bearing steel.

In the practical field, a number of works were reported; abnormal wear of piston rings in marine diesel engine ${ }^{166)}$, cylinder liner wear in high speed diesel engine ${ }^{107}$, the relation between wear and dust in an internal combustion engine ${ }^{168}$, the effect of lubricating oil additives on lubricating properties of worm gear $^{(69)}$, scoring ${ }^{170)}$ and pitting ${ }^{171-174)}$ of gears, and wear of machine tool slideways, the measurement of engine wear, using radioisotopes ${ }^{176)-178)}$ and the test methods of shear stability of lubricating oils ${ }^{179)-185)}$.

Fundamental studies were made on gear lubrication, such as analysis on discontinuous phenomena ${ }^{186)}$ and dynamic phenomena of oilfilm ${ }^{187), 188}$, heat transfer in lubricating oilfilm ${ }^{189,190)}$, and temperature distribution and oil-film thickness in journal bearings ${ }^{191}$.

Of other studies in this field, there are papers on lubrication of bevel gear ${ }^{192)}$, oil jet lubrication in ball bearings for gas turbines ${ }^{193}$, oil jet and oil mist lubrication in roller bearings for jet engines ${ }^{194}$ lubrication in plastics processing ${ }^{195,},{ }^{196)}$ and electrified lubrication for metal frictional surfaces ${ }^{197}$.

\section{References}

1) Y. Sakai et al., J. Japan Petol. Inst., 8, (1), 36 (1965).

2) Y. Sakai et al., ibid., 9, (6), 463 (1966).

3) T. Kotani et al., ibid., 7, (4), 225 (1964).

4) S. Funakoshi et al., ibid., 8, (6), 428 (1965).

5) T. Furukawa et al., Bull. Japan Petrol. Inst., 6, 1 (1964).

6) K. Iijima et al., J. Japan Petrol. Inst., 6, (1), 20 (1963).

7) Y. Oguchi et al., Lecture at the 18th Annual Meeting of Chem. Soc. of Japan, (1965).

8) K. Tarama et al., J. Fuel Soc. of Japan, 42, 42 (1963).

9) A. Okagami et al., Lecture at the 7th Meeting of Japan Petol. 85, Inst., (1964).

10) T. Yamaguchi et al., J. Japan Petrol. Inst., 6, (3), 197 (1963).

11) Y. Kunugi et al., Lecture at the 19th Annual meeting of Chem. Soc. of Japan, (1966) 
12) N. Yamamoto et al., J. Japan Petrol. Inst., 9, (1) 30 (1966).

13) N. Yamamoto et al., ibid., 9, (7), 531 (1966).

14) H. Yoshida et al., ibid., 8, (4), 249 (1965).

15) H. Yoshida et al., ibid., 8, (12). 940 (1965).

16) H. Yoshida et al., ibid., 9, (1), 21 (1966).

17) H. Hayashi et al., ibid., 8, (4), 254 (1965).

18) N. Yata, ibid., 7, (12), 877 (1964).

19) N. Yata et al., Bull. Japan Petrol. Inst., 8, 7 (1966).

20) N. Sakikawa et al., Lecture at the 8th Annual Meeting of Japan Petrol. Inst., (1965).

21) M. Hirohama et al., Lecture at the 18th Annual Meeting of Chem. Soc. of Japan, (1965).

22) S. Shuto et al., J. Japan Petrol. Inst., 9, (5), 338 (1966)

23) S. Takiguchi et al., ibid., 9, (5), 346 (1966).

24) Y. Uto et al., ibid., 9, (5), 354 (1966).

25) T. Hiramatsu et al., ibid., 9, (5), 360 (1966).

26) A. Toba, ibid., 9, (5), 366 (1966).

27) M. Kawaguchi, ibid., 9, (5), 371 (1966).

28) T. Kunugi et al., ibid., 7, (3), 168 (1964).

29) T. Kunugi et al., Lecture at the 17th Annual Meeting of Chem. Soc. of Japan, (1964).

30) H. Miyake et al., Bull. Japan Petrol. Inst., 5, 58 (1963).

31) H. Miyake et al., Lecture at the 17 th Annual Meeting of Chem. Soc. of Japan, (1964).

32) S. Tago et al., ibid., the 18th, (1965).

33) S. Tago et al., J. Japan Petrol. Inst., 6, (10), 803 (1963).

34) S. Tago et al., Bull. Japan Petrol. Inst., 7, 1 (1965).

35) I. Takizawa et al., Lecture at the 18th Annual Meeting of Chem. Soc. of Japan, (1965).

36) I. Takizawa, ibid., (1965).

37) I. Watanabe et al., J. Japan Petrol. Inst., 8, (6) 436 (1965).

38) E. Nakamura et al., ibid., 9, (8), 634 (1966).

39) S. Oshima et al., Lecture at the 16th Annual Meeting of Chem. Soc. of Japan, (1963).

40) S. Oshima et al., J. Chem. Soc. of Japan (Ind. Chem. Sec.), 84, 646 (1963).

41) S. Oshima et al., Lecture of the 17th Annual Meeting of Chem. Soc. of Japan, (1964).

42) S. Oshima et al., ibid., the 18th, (1965).

43) A. Shimazu et al., J. Japan Soc. Lub. Eng., 11 , 195 (1966)

44) A. Shimazu et al., J. Japan Petrol. Inst., 8, (4), 267 (1965).

45) S. Tanaka et al., Lecture at the 17th Annual Meeting of Chem. Soc. of Japan, (1964).

46) K. Hasegawa et al., Bull. Japan Petrol. Inst., 6, 19 (1964).

47) K. Hasegawa et al.. Japan the Analyst, 14, 717 (1965).

48) K. Hasegawa et al., ibid., 13, 93 (1964).

49) 0 . Shimoda et al., Lecture at the 18th Annual Meeting of Chem. Soc. of Japan, (1965)

50) K. Ishida et al., ibia., the 16th, (1963).

51) S. Musha et al., Japan Analyst, 14, 886 (1965).

52) S. Musha et al., Lecture at the 18th Annual Meeting of Chem. Soc. of Japan, (1965).

53) S. Musha et al., ibid., the 17t1, (1964).

54) K. Ishida et al., ibid., the 16th, (1963).
55) K. Hasegawa et al,, Japan Analyst 13, 319 (1964).

56) K. Hasegawa et al., ibid., 14, 70 (1965).

57) T. Takeuchi et al., Lecture at the 17th Annual Meeting of Chem. Soc. of Japan, (1964).

58) S. Sato et al., J. Japan Petrol. Inst., 8, (6), 432 (1965).

59) Y. Nose et al., Lecture at the 6th Meeting of Japan Petol. Inst., 104 (1963).

60) T. Omori et al., J. Japan Petrol. Inst., 7, (4), 230 (1964).

61) K. Muroi et al., Bull. Japan Petrol. Inst., 8, 45 (1966).

62) M. Onoyama et al., J. Japan Petrol. Inst., 8, (4), 263 (1965).

63) M. Kinoshita et al., ibid., 8, (4), 259 (1965).

64) M. Kinoshita et al., ibid., 7, (1), 20 (1964).

65) K. Kasamatsu, ibid., 6, (10), 774 (1963).

66) S. Morimoto, ibid., 6, (10), 794 (1963).

67) I. Shimizu, Lecture at the 8th Meeting of Japan Petrol. Inst., (1965).

68) T. Shigeta, J. Japan Petrol. Inst., 6, (10), 766 (1963).

69) K. Yamazaki et al., ibid., 6, (8), 597 (1963).

70) K. Yamazaki et al., ibid., 6, (8), 602 (1963).

71) T. Mori et al., ibid., 8. (1), 29 (1965).

72) T. Mori et al., ibid., 8, (2), 97 (1965).

73) T. Mori et al., ibid., 8, (10), 767 (1965).

74) T. Mori et al., ibid., 8, (12), 946 (1965).

75) T. Mori et al., Bull. Japan Petrol. Inst., 7, 7 (1965).

76) T. Ogawa, J. Fuel Soc. of Japan, 43, 253 (1963).

77) The Road Octane Number Committee of the Japan Petrol. Inst., J. Japan Petrol. Inst., 8, (9), 663 (1965).

78) K. Uchinuma et al., Bull. Japan Petrol. Inst., 6, 26 (1964)

79) K. Uchinuma et al., ibid., 6, 35 (1964).

80) K. Uchinuma et al., SAE Paper, 967B (1965).

81) Takahashi, Combustion Symposium (Japan) preprint (1964).

82) Y. Yuhara et al., Bull. Japan Petrol. Inst., 8, 51 (1966).

83) A. Arai, Fuel and Combustion 31, 321 (1964).

84) N. Kita et al., Japanese National Railways, Technical Research Report (432), 1 (1964).

85) S. Jo, Trans. of the J. Soc. of Mech. Eng., 32, (233), 116 (1965).

86) M. Seo et al., ibid., 31, (224), 642 (1965).

87) F. Nagao et al., ibid., 31, (230), 1533 (1965).

88) The 5th Research Division of Japan Petrol. Inst. $J$. Japan Petrol. Inst., 7, (3), 178 (1964).

89) H. Iijima et al., J. Japan Petrol. Inst., 8, (8), 610 (1965).

90) T. Sagai et al., J. Chem. Soc. Japan (Ind. Chem. Sec.), 68, 736 (1965).

91) Y. Arai et al., J. Japan Petral. Inst., 9, (7), 536 (1966).

92) I. Shimazu, Lecture at the 8th Meeting of Japan Petrol. Inst., (1965).

93) S. Kamio et al., Lecture at the 17th Annual Meeting of Chem. Soc. of Japan (1964).

94) T. Sakurai et al., Lecture at the 8th Meeting of Japan Petrol. Inst., (1965).

95) T. Sakurai et al., ibid., the 6th, 151 (1963).

96) T. Sakurai et al., Lecture of the 19th Annual Meeting of Chem. Soc. of Japan, (1966). 
97) T. Sakurai et al., Lecture at the 6th of Japan Petrol. Inst., 158 (1963).

98) T. Sakurai et al,, ibid., the 7th, 73, (1964).

99) T. Sakurai et al., ibid., the 6th, 173, (1963).

100) N. Yamaki et al., J. Japan Soc. Lub. Eng., 9, 307 (1964).

101) K. Kishigami et al., ibid., 9, 307 (1964).

102) Y. Nose, The 6th Conference of Radioisotopes, (1964).

103) S. Furuhama et al., Trans. of Japan Soc. Mech. Eng., 31, 1040 (1965).

104) S. Furuhama et al., Japan Soc. Mech. Eng. Meeting Preprint, No 150 (1966).

105) K. Hasegawa et al., Lecture at the 9th Meeting of Japan Petrol. Inst., 66 (1966).

106) H. Shibusawa et al., J. Japan Soc. Lub. Eng., 9, 247 (1964).

107) M. Ishimaru et al., ibid., 9, 229 (1964).

108) M. Ishimaru et al., J. Japan Soc. Lub. Eng., 9, 235 (1964).

109) T. Yokoyama et al., ibid., 9, 495 (1964).

110) M. Tsuge et al., Japan Soc. Mech. Eng. Meeting Preprint, No. 152 (1966).

111) S. Furuhama et al., J. Japan Soc. Lub. Eng., 8, 397 (1963).

112) S. Kamio et al., ibid., 9, 253 (1964).

113) S. Yoshida et al., Japanese National Railways Technical Research Report, No. 65194 (1966).

114) T. Yoshino et al., J. Japan Soc. Lub. Eng., 9, 223 (1964).

115) Y. Sakai et al., Lecture at the 17th Annual Meeting of Chem. Soc. of Japan, (1964).

116) Y. Wakuri et al., J. Japan Soc. Lub. Eng., 10, 104 (1965).

117) M. Katsuta, ibid., 9, 465 (1964).

118) M. Ogawa, ibid., 8, 21 (1963).

119) A. Wakana et al., ibid., 8, 339 (1963).

120) M. Ishimaru et al., Lecture at the 19th Annual Meetlng of Chem. Soc. of Japan, (1966).

121) T. Ohashi et al., ibid., the 16th, 1 (1963).

122) M. Nagano et al., Bull. Japan Petrol. Inst., 4, 45 (1962).

123) M. Hoshino, J. Japan Soc. Lub. Eng., 9, 29 (1964).

124) T. Oguchi et al., ibid., 8, 266 (1963).

125) T. Shonozaki et al., ibid., 8, 237 (1963).

126) Y. Moniwa et al., ibid., 10, 101 (1965).

127) S. Ono et al., ibid., 8, 261 (1963).

128) A. Kobayashi, ibid., 11, 264 (1966)

129) K. Ono et al., ibid., 8, 243 (1963).

130) Y. Moniwa., ibid., 8, 49 (1963).

131) T. Chiku et al., Lecture at the 16th Annual Meeting of Chem. Soc. of Japan, (1963).

132) K. Oma et al., Corrosion Eng., 15, (5), 201 (1966).

133) H. Sugawara et al., J. Japan Soc. Mech. Eng., 29, 1210 (1965).

134) S. Fujii et al, Corrosion Eng., 12, 179, 365, 424 (1963); 13, 153, 202 (1964).

135) M. Koike et al., Rust Prevention Control, 6, (2), 9 (1962).

136) K. Saeki et al., J. Japan Soc. Technology Plasticity 6, 439 (1965).

137) K. Saeki et al., ibid., 7, 183 (1966).

138) E. Tanaka et al., ibid., 6, 148 (1965).

139) T. Mizuno, ibid., 7, 383 (1966).

140) A. Yoshioka, J. Japan Soc. Lub. Eng., 9, 82 (1964).

141) M. Nagano et al., Lecture at the 18th Annual Meeting of Chem. Soc. of Japan, (1965).

142) Y. Moniwa et al., J. Japan Soc. Lub. Eng., 8, 85 (1963).

143) H. Kurosawa, Cent. Research Inst. of Elect. Power Industry, Technical Report, (64054), 1 (1964).

144) H. Fujita, J. Chem. Soe. of Japan (Ind. Chem. Sec.), 67, 1680 (1964).
145) S. Kimura et al., Lecture at the 7 th Meeting of Japan Petrol. Inst., 67 (1964).

146) S. Sakagami et al., J. Chem. Soc. of Japan (Ind. Chem. Sec.) 67, 1589 (1964).

147) K. Murayama, J. Fuel Soc. Japan, 42, 480 (1963).

148) K. Murayama, ibid., 43, 191 (1964).

149) M. Otsuka et al., Lecture at the 16th Annual Meeting of Chem. Soc. of Japan (1963).

150) H. Iijima et al., J. Japan Petrol. Inst., 8, (10), 772 (1965).

151) T. Horio et al., ibid., 6, (3), 183 (1963).

152) C. Itakura et al., Bull. Japan Petrol. Inst., 8, 57 (1966).

153) T. Sugawara et al., ibid., 8, 68 (1966).

154) K. Murayama., J. Fuel Soc. Japan, 42, 747 (1963).

155) H. Shibusawa et al., Asphalt, 8, (43), (1965).

156) K. Mine et al., ibid., 7, (36), (1964)

157) K. Murayama, J. Fuel Soc. Japan, 43, 112 (1964).

158) M. Koike et al., ibid., 44, 46 (1965).

159) H. Marumo et al., Lecture at the 16th Meeting of Chem. Soc. of Japan (1963).

160) M. Toyoguchi et al., J. Japan Soc. Lub. Eng., 9, 100 (1964).

161) M. Toyoguchi et al., ibid., 10, 19 (1965).

162) M. Toyoguchi et al., ibid., 10, 27 (1965).

163) Y. Takai, ibid., 10, 501 (1965).

164) A. Yoshioka, ibid., 9, 298 (1964).

165) S. Aoki et al., ibid., 8, 165 (1963).

166) Y. Wakuri et al., J. Japan Soc. Mech. Eng., 66, 1560 (1963).

167) T. Nakashiro, ibid., 67, 1164 (1964).

168) B. Ito et al., Science of Machine, 15, 31 (1963).

169) H. Ueno et al., Trans. of Japan Soc. Mech., Eng., 30, 437 (1964).

170) J. Takada et al., J. Mechanical Laboratory of Japan, 19, 77 (1964).

171) S. Hashimoto, Trans. of Japan Soc. Mech. Eug., 29, 1428 (1963).

172) S. Hashimoto, ibid., 29, 1436, (1963).

173) J. Takada, J. Mechanical Laboratory of Japan, 19, 91 (1964).

174) K. Kaneko et al., Trans. of Japan Soc. Mech. Eng., 30, 388 (1964).

175) Y. Goto et al., J. Metal Finishing Soc. of Japan, 16, 101 (1965).

176) S. Maruyama et al., J. Soc. Automotive Eng. of Japan, 17, 497 (1963).

177) N. Yamaki et al., J. Japan Soc. Lub. Eng., 9, 239 (1964).

178) K. Kishigami et al., ibid., 9, 307 (1963).

179) S. Nogami, ibid., 8, 71 (1963).

180) S. Nogami, ibid., 10, 359 (1965).

181) S. Nogami, ibid., 11, 105 (1966).

182) S. Nogami, ibid., 11, 155 (1966).

183) S. Nogami, ibid., 11, 159 (1966).

134) M. Shiosawa et al., ibid., 11, 242 (1966).

185) M. Fujita et al., ibid., 11, 257 (1966).

186) T. Sasaki et al., Trans. of Japan Soc., Mec. Eng.,

187) T. Sasaki et al., ibid., 32, 1287 (1966).

188) T. Sasaki et al., ibid., 32, 1296 (1966).

189) H. Tahara, J. Japan Soc. Lub., Eng., 9, 369 (1964).

190) H. Tahara, ibid., 11, 247 (1966).

191) A. Hida, ibid., 11, 111 (1966)

192) H. Ueno, J. Japan Soc. Mech. Eng., 66, 785 (1963).

193) H. Minata, J. Japan Soc., Lub. Eng., 10, 423 (1965).

194) H. Minata, ibid., 9, 378 (1964).

195) E. Tanaka et al., J. Japan Soe. for Technology of Plasticity, 6, 148 (1965).

196) Y. Kasuga et al., ibid., 6, 189 (1965).

197) S. Nakamura et al., J. Japan Soc. Lub. Eng., 9, 21 (1964). 